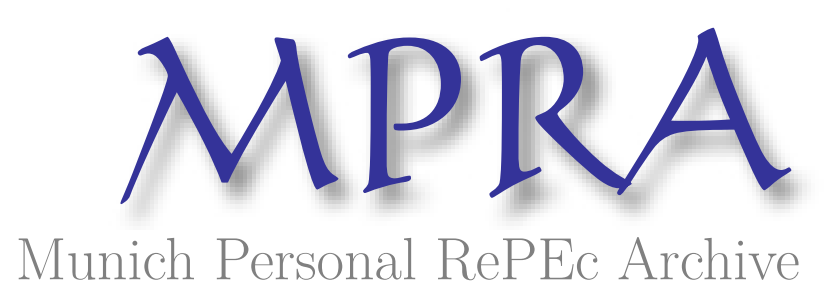

\title{
Perceptions about the mass media among the students from Republic of Moldova
}

Stefanescu, Razvan and Dumitriu, Ramona and Nistor, Costel

Dunarea de Jos University of Galati, Dunarea de Jos University of Galati, Dunarea de Jos University of Galati

23 March 2011

Online at https://mpra.ub.uni-muenchen.de/41622/

MPRA Paper No. 41622, posted 01 Oct 2012 13:26 UTC 


\title{
PERCEPTIONS ABOUT THE MASS MEDIA AMONG THE STUDENTS FROM REPUBLIC OF MOLDOVA
}

\author{
RAZVAN STEFANESCU \\ RAMONA DUMITRIU \\ COSTEL NISTOR
}

\author{
Faculty of Economics and Business Administration \\ UNIVERSITY “DUNAREA DE JOS” GALATI
}

\begin{abstract}
The last decades revealed the importance of mass media in a society. Regarding the Republic of Moldova the role of mass media is influenced by some particularities of the economic, politic and social activities. Moldova is among the poorest states from Europe and its political situation is still unstable. On the markets of mass media from Moldova there are in competition different categories of participants: domestics and foreigners, public and private entities. This paper presents the results of an investigation among a group of students from the Republic of Moldova regarding their perceptions about mass media. Such results could contribute to understanding the impact of mass media for an important segment of the Bessarabian society.
\end{abstract}

Keywords: Mass Media preferences, Trust in Mass Media, Bessarabian Students JEL Classification: H49, H89, L33

\section{INTRODUCTION}

The major impact of mass media in a society was approached in several scientific papers. Some of them revealed the strong relationship between the use of media and the political attitudes $[1,2,3]$. Others proved the growing role of mass media news in politics $[4,5,6,7]$. In this context the freedom and the objectivity of media are considered to be among the main obstacles to autocracy and corruption $[8,9]$. The freedom and the objectivity of media depend not only on the control or influence of the government but also by the ownership of media $[10,11,12]$.

In this paper we investigate the perceptions about the mass media among the students from the Republic of Moldova. As an independent state, Moldova has a quite short history. For centuries its territory belonged to the medieval principality of Moldavia. In 1812 the east half of Moldavia, later called Bessarabia, was annexed by the Russian Empire.

In April 1918 Bessarabia united with Romania. In June 1940, as a consequence of Molotov - Ribbentrop Pact, Bessarabia was annexed to the Soviet Union. For almost three years, during the Second World War, Romania regained Bessarabia but finally the territory was reincorporated to the Soviet Union as the Moldavian Soviet Socialist Republic. In August 1991, in the context of the Soviet Union disintegration, the Republic of Moldova declared its independence. Since its independence the political situation from the Republic of Moldova was quite unstable.

The concepts of the national language and even the Moldovan nation are still objects of controversies. Many citizens of Bessarabia consider themselves as Romanians, speaking the Romanian language. However, their vision is not shared by the authorities from Republic of Moldova.

Some parties are favourable to strong relations with Romania and European Union, while other parties prefer the relations with Russia. From 2001 to 2009 the Republic of Moldova was ruled by the Party of Communists, a political formation favourable to strong relations with Russia. In April 2009, after the disputed 
parliamentary elections, some non governmental organizations and opposition parties organized protests in the capital of the country Chisinau, forcing the communists to leave the power. Since then a coalition of the pro European Union parties obtained a fragile majority in the Parliament. For the next years there are expected new elections with decisive results for the future of Moldova.

Since the independence, some significant transformations occurred in the Republic of Moldova media. Some economic, demographic and politic particularities influenced this evolution. In terms of Gross Domestic Product Moldova was the poorest country in Europe. From its 3.5 millions of citizens about 70 percent are Moldovan or Romanian people, while Ukrainian and Russian people represent about 30 percent. There were accusations that, although media was formally free, the government influence was substantial.

This paper presents the results of an investigation in which 54 students from the Republic of Moldova were questioned about mass media. Obviously, this sample is too small for generalizing. However, its results could help in understanding the impact of mass media on the Bessarabian society.

\section{DATA AND METHODOLOGY}

In our investigation we used a sample of 54 Bessarabian students from a branch of a Romanian university localised in Cahul (a town from the Republic of Moldova, closed to the border with Romania, with an estimated population of about 40000). All of them are Moldovan (Romanian) natives but they also studied the Russian language in school. Their ages are between 18 and 20 years.

Our investigation occurred between January and April 2011. We collected data from individual interviews. We approached as main subjects:

- mass media preferences;

- $\quad$ trust in mass media.

\section{EMPIRICAL RESULTS}

We asked the 54 students about how often they watch television, how often they listen to the radio or how often they read magazines. Their answers indicated an obviously preference for television (Table 1).

We transposed these answers on a rating scale from 1 to 5 ( 1 for "very low" and 5 for "very high"). The descriptive statistics resulted confirmed the supremacy of television and radio over magazines (Table 2).

Regarding television the students indicated various channels. Some of them are from Moldova, like Moldova 1 and Publika TV, others are Romanian, like TVR 1 and PRO TV or Russians, like Prime and TNT.

35 students (64.8 percent) considered that Russian television channels are more attractive than the Moldovan or the Romanian ones. They explained they were interested mostly in the entertainment programs. In their opinion the Russian channels provided a better quality entertainment programs than the Moldovan and the Romanian ones.

Regarding the radio students answers indicated a net preference for the Romanian channels, especially Kiss FM and Europa FM. They also listen to Moldovan channels and seldom to Russian or Ukrainian channels.

From the students answers it resulted they preferred mainly the local magazines. Some of them read the online editions of the Romanian magazines.

The interviews revealed that no student trusted the public television or radio from the Republic of Moldova. Both of them practically ignored the protests from April 2009 and the students considered that as an evidence of the total control of authorities over mass media. Students also believe that private mass media from Bessarabia is serving owner's interests. 43 students (79.6 percents) trusted in the objectivity of public mass media from Romania and they used it frequently as a source of information about the Republic of Moldova. However, only 8 
of them (14.8 percents) considered that private mass media from Romania as objective. 14 students (25.9 percents) trusted in the Russian private mass media and they used it as a source of information about their country.

We also questioned the students about the impact of mass media in politics. It resulted that all of them were informed about politics mainly by the television. It also resulted that a significant number of students were interested not only in the political situation from the Republic of Moldova, but also from Romania and Russia (Table 3).

The students interested in the political situation from Romania explained they considered this country as the main supporter of the Republic of Moldova strengthening relations with the European Union. The interest for the political situation from Russia was justified by significant economic relations between this country and the Republic of Moldova.

\section{CONCLUSIONS}

In this paper we approached the perceptions of a group of Bessarabian students about mass media. We found that television was more preferred in comparison with radio or magazines. It also resulted that students attended not only Moldovan mediums but also Romanian and Russian ones.

Such preferences could be explained by Republic of Moldova's past. Belonging to Russia and then to the Soviet Union contributed to the attraction for the Russian television from the Republic of Moldova.

The common language and the recent strengthen of relations with Romania has also a significant impact on the students' preferences. These aspects could be taken into consideration in understanding evolution of society from the Republic of Moldova.

\section{BIBLIOGRAPHY}

1. Bennett, S. E., Rhine, S. L.,
Flickinger, R. S., Bennett, L. M. (1999), Video Malaise Revisited: Public Trust in the Media and Government, The Harvard International Journal of Press / Politics (4), 8-23;

2. Cooper, Christopher A., Martin Johnson (2007), The Role of the Media in the Policy Process: Perspectives from PIOs, Legislators, and Reporters, Presented at the Seventh Annual State Politics and Policy Conference, University of Texas, Austin, Texas, February 23-24, 2007;

3. Moy, P., Scheufele, D. A. (2000), Media Effects on Political and Social Trust, Journalism and Mass Communication Quarterly, 77(4), 744-759;

4. Jones, Alex (2009), Losing the News:

The Future of the News That Feeds

Democracy. Oxford University Press;

5. De Vreese, C. (2004), The Effects of Strategic News on Political Cynicism, Issue Evaluations and policy Support: A TwoWave Experiment, Mass Communication and Society, 7(2), 191-214;

6. Kleinnijenhuis, J., van Hoof, A. M., Oegema, D. (2006), Negative News and the Sleeper Effect of Distrust, Harvard International Journal of Press / Politics, 11(1), 86-104;

7. Patterson, T. E. (1996), Bad News, Bad Governance, Annals of the American Academy of Political and Social Science, 546, 97-108;

8. Pfau, M., Moy, P., Holbert, L. R., Szabo, E. A., Lin, W. - K., Zhang, W. (1998), The Influence of Political Talk Radio on Confidence in Democratic

Institutions, Journalism and Mass

Communication Quarterly, 75(4), 730-745;

9. Baker, C. Edwin (2002), Media,

Markets, and Democracy, New York:

Cambridge University Press;

10. Norris, P. (2000), The Impact of

Television on Civic Malaise, In S. J. Pharr \&

R. D. Putnam (Eds.), Disaffected democracies: What's troubling the trilateral countries? Princeton, New Jersey: Princeton University Press;

11. Entman, Robert M. (2005), The

Nature and Sources of News, In Geneva Overholser and Kathleen Hall Jamieson, 
eds. Institutions of American Democracy: The Press, New York: Oxford University Press;

12. Lynch, G. Patrick (2003), The Media in State and Local Politics, In Mark J.

Rozell, ed. Media Power, Media Politics, Lanham, MD: Rowman and Littlefield Publishers.

\section{APPENDIX}

Table 1 - Students preferences for mass media

\begin{tabular}{|c|c|c|c|}
\hline Medium & TV & Radio & Magazines \\
\hline Frequency & & & \\
\hline Very High & 33 & 27 & 9 \\
\hline Hoderate & 15 & 19 & 23 \\
\hline Low & 6 & 5 & 16 \\
\hline Very Low & - & 3 & 2 \\
\hline Total & - & - & 54 \\
\hline
\end{tabular}

Table 2 - Descriptive Statistics of Students preferences for mass media

\begin{tabular}{|c|c|c|c|}
\hline Indicator & TV & Radio & Magazines \\
\hline Mean & 4.500 & 4.444 & 2.944 \\
\hline Standard Error & 0.094 & 0.082 & 0.131 \\
\hline Median & 5.000 & 4.500 & 3.000 \\
\hline Mode & 5.000 & 5.000 & 3.000 \\
\hline Standard Deviation & 0.694 & 0.604 & 0.960 \\
\hline Sample Variance & 0.481 & 0.365 & 0.921 \\
\hline Kurtosis & -0.131 & -0.547 & -0.094 \\
\hline Skewness & -1.057 & -0.580 & 0.380 \\
\hline Sum & 243.000 & 240.000 & 159.000 \\
\hline Count & 54.000 & 54.000 & 54.000 \\
\hline $\begin{array}{c}\text { Confidence Level } \\
(95.0 \%)\end{array}$ & 0.189 & 0.165 & 0.262 \\
\hline
\end{tabular}

Table 3 - Students' interest about the political situation from the Republic of Moldova, Romania and Russia

\begin{tabular}{|c|c|c|c|}
\hline Country & Moldova & Romania & Russia \\
\hline Very Interested & 42 & 21 & 14 \\
\hline Quite Interested & 12 & 33 & 22 \\
\hline Not Interested & - & - & 18 \\
\hline Total & 54 & 54 & 54 \\
\hline
\end{tabular}

